\title{
TRUST AS A CONDITION OF GETTING TO KNOW THE TRUTH: THE ANTHROPOLOGICAL ASPECT
}

Trust is a fundamental ingredient of community life, present in all its aspects. Thanks to it building permanent interpersonal relations is possible. The lack of it results in people becoming asocial and unable to take any action. You can say that social life without trust is simply impossible (Piotr Sztompka, 2007). However, trust also has aspects that are sometimes abused. For some time now, as certain insufficiency of law is observed, people are encouraged to trust institutions. On the other hand, trust is a value that in everyday human relations is getting more and more marginalised ${ }^{1}$.

Without trust there are no deepened social relations, nor is full human development, assuming spiritual element, possible. One of the most interesting descriptions of spirituality as "life of life" calls for some complement. Where to draw this "life" for "life" from? Human life, in a difference from other forms of life, requires references that involve entire man, not only in the existential aspect, but also - perhaps above all - in the personal one. Man is not looking, however, for any kind of relations, he is a personal being, which assumes a double

${ }^{1}$ Lecture given on the 17th November, 2015 at the Cardinal Stefan Wyszyński University in Warsaw, during the conference on Question of Trust in Ecumenical and Moral Perspective. Cf. J.A. S o b k o w i a k, Prawda w społeczeństwie pluralistycznym i tolerancyjnym [Truth in a pluralistic and tolerant society], „Teologia i Moralność" [Theology and Morality], 2(2007) pp. 49-64. 
nature of his references: to people and to truth. By truth I mean here not just some logical or metaphysical coherence, but first of all truth as trust in the person that testifies it ${ }^{2}$.

Man is also a moral being. And morality has its source in the faith in God who reveals his love for man. You can therefore say paraphrasing St Paul's words - that moral life is "obedience of faith" (cf. Romans 1, 5, 16, 26), expressed in trusting and consequently confiding in God. It is not so much a matter of human belief (adapted to human tastes, expectations and surveys), but the virtue of faith, which is always a grace of clinging to God rationally and freely ${ }^{3}$. It is expressed not so much in act of believing in something, as rather in an act of confiding in someone who makes you believe. I do not believe in God thanks to something, but due to confiding in God I accept what He reveals.

In a slightly different aspect, but similar scheme, trust is an indispensable element in human communication, but also in discovering and communicating the truth. And this discovering of trust as a condition of getting to know the truth is what this lecture is dedicated to.

\section{WHAT IS TRUTH?}

The classical definition of truth ${ }^{4}$ shows a specific relation between the result of knowing (in the intellect) and the object of knowing (in the thing). We may find the sources of this concept as early as in Plato, who in his Sophist dialogue expounds the concept of combining truth and being. Plato expresses this in the following way: if [something] exists, it must refer to something and cannot refer to nothing ${ }^{5}$. [...] A true sentence tells something about you as it is, and a false one

${ }^{2}$ CCC 177.

${ }^{3}$ Cf. Bishop W. D e p o, Homily at Jasna Góra during the 17th Pilgrimage of the Family of Radio Maryja, after Vatican Radio Service of 12th July, 2009.

${ }^{4} \mathrm{~L}$. O s t a s z, Czym jest prawda $w$ szerokim tego stowa znaczeniu? [What is True in the broad sense of the Word], Warsaw 2010, pp. 15-28.

5 P 1 a t o, Sophist, 262e. 
says something different to what is; it therefore talks about something that does not exist in such a way as though it existed ${ }^{6}$.

But the fundamental intuition associated with the concept of truth was formulated by Aristotle? In his Metaphysics Aristotle affirms that one tells the truth when one says about something which exists, that it exists, and about something that does not exist - that it does not $^{8}$. The truthfulness of statements on truth consists in its congruence with reality 9 . It was to this definition that St Thomas referred, defining truth as follows: Veritas est adaequatio intelectus et rei secundum quot intelectus dicit esse quo est et non quot non est. In order not to engage in arguments about the up-to-dateness of this «adequacy», let us assume it is a basic definition, the purpose of which is not to redefine truth, but to put the original definition within the realities of life. It is worth adding that in the definition proposed by St Thomas truth is formulated in a positive way, while in Ancient Greece $\alpha-\lambda \eta \dot{ } \Theta \varepsilon \dot{\alpha}^{\alpha}$ had a negative sense, being a negated noun, the root of which is preceded by the prefix $\alpha$ - and means: not hidden, not made secret, not forgotten. You should remember that the Greeks used the

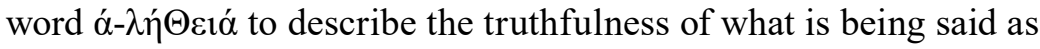
well as the veracity of the speaker ${ }^{10}$.

In the light of the above explanations, truth is a non-hiddenness of being, its disclosure or accessibility. For truth is an openness of being

6 Ibid., 263b.

${ }^{7}$ Historians of philosophy indicate, however, that the idea of corresponding truth appeared earlier in Plato or even in Parmenides, which was suggested in the paper. In a wide range the concept of truth in Antiquity is elaborated on by J. Woleński in his Epistemologia, $t$. 1. Zarys historyczny i problemy metateoretyczne, Ureus, Kraków, 2000 [Epistemology vol. 1. Historical Outline and Meta-theoretical Problems] pp. 40-47.

${ }^{8}$ Cf. A r is tot le, Metaphysics 1012a; $1051 \mathrm{~b}$.

9 Cf. J. M i s i e k, O filozoficznych definicjach pojeccia prawdy [On the Philosophical Definitions of the Concept of Truth], „Kwartalnik filozoficzny” [Philosophical Quaterly], 32(2004), b. 2, pp. 24-25.

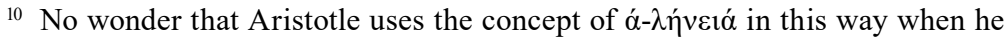
says that contiguity with thing and affirmation is truth. Cf. Aristotle, Metaphysics, 1051b; Nicomachean Ethics, 1108a. 
towards getting known, it is the reason for its intelligibility. You can therefore say that precisely because it is not hidden, it is apprehensible. So if anything exists at all, i. e. is a being, it is not hidden for the intellect.

Getting to know the truth is both simple and difficult. The ancient rendered this as an image of a house. It is simple: you cannot miss the door. It is difficult: apprehending truth as a whole, you often fail to understand its parts. Let us consider asking a question. The easiness and difficulty of answering it is not the same as easiness and difficulty of formulating an answer or writing it on paper: it concerns power and skill. What is easy for some, may be very difficult for others. It shows that the difficulty lies not only in the objective aspect of truth, but also in what is difficult for the subject ${ }^{11}$. In the scholasticism the sense of the difference was rendered by the pair of concepts: Patetpatent. Patet means the openness of truth and patent-a specific key to getting to know it ${ }^{12}$.

Another question is the absolute nature of truth. It is attributed to truth and not to a person, so that not every sentence uttered by a person seeking the truth has an absolute value. For example, you often can hear the phrase: I agree with you absolutely. It does not mean that you agree with the person speaking, but with what that person said on the particular, strictly defined issue. However, you can live a partial truth. In other words, absolute truth does not tie beings between themselves, but ties them to the object of perception. Whereas a partial truth ties beings, but may result to be far from absolute truth ${ }^{13}$.

11 J. D ę b ow sk i, Prawda i warunki jej możliwości[Truth and its Conditions of possibility], Olsztyn 2010, pp. 75-79.

${ }_{12}$ M. G łow a la, Łatwość i trudność poznania prawdy, in: J. Ja s k ó ła, A. O l e j a r c z y k (red.), Prawda a metoda [Truth and Method], part II O prawdzie [On Truth], Wrocław 2006, pp. 53-60.

${ }_{13}$ Cf. R. Z i e m i ń s k a, Czy można dziś obronić absolutyzm w teorii prawdy? [Is It Possible Today to Defend Absolutism in the Theory of Truth?], „Acta Universitatis Wratislaviensis" 2006 n 2856, v. XLIV: Prawda a metoda [Truth and Method], part II O prawdzie [On Truth], ed. J. J a s k ó ł a, A. O l e j a r c z y k, Wrocław 2006. p. 135. See also H. P u t n a m, Wiele twarzy realizmu i inne eseje [The Many Faces of Realism and other Essays], trans,. A. Grobel, PWN, Warszawa 1998. 
In practice, a partial concept of truth is made absolute. Thus the difference between absolute and non-absolute truth consists in that absolute truth refers to an object and a partial one to a definite set of truths or utterances.

Truth is expressed in words, but nobody is its owner. Man is only the owner of a fragmentary expression of truth in utterance. Truth has therefore a certain ecumenical aspect, it is a communication between separate subjects. On one hand the quest for truth consists in subjects getting closer, on the other hand - in approaching the meaning and sense of their utterances. Thus truth is a way of building a community around what exists. On the condition that reaching the fruit of truth is achieved by way of communicating oneself in the discovered sense of one's own existence. What deprives truth of objectivism is its detachment not only from an object but also from the subject that seeks it, and on finding tries to express it.

\section{COMMUNICATION OF TRUTH}

Adaequatio can only be lived in a subject. However, for the truth to live, it must be incessantly discovered, through attempts to express the same things "anew". Such representation has to take into account four elements: 1 / truth needs relations; 2 / in order to live, truth needs words; 3 / words in their turn need expression in images; 4/ proposing the right image translates into truthfulness of the world of utterances and the horizon of their understanding.

\section{a) Truth requires relations}

As H. Urs von Balthasar remarks ${ }^{14}$, truth in the full sense exists only in full being. It means that truth about an object only happens when a subject approaches. In a way it is the subject that gives sense

${ }_{14}$ More on the freedom of the subject is to be found in H.U. von B a l t h a s a r, Teologika. 1. Prawda świata [Theo-Logic. The Truth of the World], (trans.) J. Zychowicz, Kraków 2003, pp. 101-113. 
to an object. It is undoubtedly true in reference to infinite being, but can we risk a similar thesis concerning man? ${ }^{15}$ The best proof of this inability of man is that not only cannot he decide God-like about giving sense to a thing, but even cannot entirely give sense to himself.

On the other hand, an existing man has such a strong self that lets him determine - as contrary to things - the level of the so called intimacy of being, or the extent of openness. In other words, man cannot decide when to appear in the world, but can decide how to do it. Communicating himself he can determine the level of intimacy of his own being, i. e. the extent of his openness. But he can also feign openness simply by lying. Ultimately then getting to know the truth is doing it in love and trust, without which one cannot learn the truth, and certainly one cannot communicate $\mathrm{it}^{16}$.

Maybe this is why it is so hard for man to acknowledge the fact of being created. For being created means being in a relation, specifically dependent on God. And this means being in love. Thus man becomes a being of truth only when he becomes a being of love $e^{17}$. It should be noted that both communication and protection of being through determining the level of intimacy requires integration of man's ability to communicate and his ability to discover/hide the truth of himself. Thus harmony in man becomes a condition for the truth communicated by him to complement the classical communication triad: communicatio-communicare-communitas. Communicatio as

15 It would be a certain variety of Cartesianism consisting in that giving sense (and since we learn sense then also existence) to the explored object would depend on human subject.

${ }^{16}$ Cf. H.U. von B a $1 \mathrm{t}$ h a s a r, Theo-Logic. 1. The Truth of the World, op. cit., p. $107 \mathrm{ff}$. These images correspond to everyday life situations when a person in love, looking at the other one, perceives him/her differently to other people, who supposedly look more objectively. The question remains, however, not so much who sees more realistically (in the sense of balancing positive and negative qualities), as who sees more truly.

${ }_{17} \mathrm{H}$. W i t c z y k, ,,Obraz Boży” w człowieku-źródło i cel działania moralnego [The Image of God in Man: Source and Aim of Moral Action], lecture given at a conference of the Moralist Theologians Association, Kamień Śląski 10th - 12th June 2007. 
the process of communicating itself, communicare as communicating something to someone and communitas as the purpose for which the process of communication is undertaken.

\section{b) Communication of truth needs words}

Every utterance of man has a meaningful aspect. It is important to such extent that St Augustine, pointing to the inter-subjective nature of word, claims that dicere actually means docere. It means that words cannot be situated only on the level of information about something, they always refer to truth about something. Augustine gives two motives for using words. The first one, per commemorationem, is always a reference to one's own past and memories; the other - to the expression of truth. It is a kind of paradox: on one hand man is the author of the words uttered, on the other hand - the words can betray man if he ceases to control them. And he ceases to control it when the words pass from the stage of being uttered to the stage of being listened to, or the last phase - that of being heard. In this particular place of betrayal of the author by the words he utter St Augustine introduces the concept of illumination. That is why man can express more than he has said and understand more than he has heard, because God with His own word enters interhuman communication, giving human words a new and fuller meaning ${ }^{18}$.

So how to combine the need to have relations with the need of saying words? This combination assumes that truth is always deciphered by man. He deciphers it referring to the object it concerns, but also relating to others, who have the right to participate in knowing the object. Nevertheless everyone learning the truth has to be aware that words communicating the truth begin to get out of the both the utterer's and the recipient's control. It means that the condition of objectivity in seeking and communicating the truth is in fact discovering

${ }_{18} \mathrm{Ph} . \mathrm{K}$ a e p p el i n, Dire la vérité. Dramatique du désir, in: Philosophie, 8 , La vérité, Institut Catholique de Paris, ed. J. Greisch, Paris 1983, pp. 145-148. 
and accepting one's dependence, and consequently limitation ${ }^{19}$. Man is not therefore owner of truth. But since he deciphers it, he has influence over its presentation, and - in this sense - the truth depends on him. You could all it truth management.

\section{c) Words need to be expressed in images}

When man looks at the simplest manifestations of life, he cannot say that he does not see in them the essence of life, and on the other hand, since he only sees manifestations of life, he cannot claim to know its essence ${ }^{20}$. The same applies to infinity. On one hand, observing that the length of life is not just a resultant of its quality, but also of some will to live, we can say that from a finite life we learn about infinity. However, we cannot say that looking at finite life we understand infinity.

We get to know a subject in a different way than an object. An object, because of a lesser grade of inapprehensibility, is less incommunicative. Whereas a subject, putting up the barrier of self, can only be fully apprehended when giving itself. Man has therefore two interior gifts: a capability of learning the truth and an ability to express or obscure it. Yet an awareness of truth cannot take place only within the subject, as in such case it would not be a genuine participation in truth, but rather an illusory perception of truth leading to self-annihilation ${ }^{21}$.

But where does the real freedom of a subject begin? Well, it does not consist only in the fact man can reveal the truth or not. It consists in that man remain free before, during and after the process of

19 In this context it is important not to identify truth and knowledge of truth. Otherwise the subject will uncritically transfer his not objective perception to the object itself, i. e. to the truth, which leads to a certain appropriation and consequently to falsification. (Cf. E. S i e $\mathrm{n} \mathrm{k}$ i e w i c z, Wolność osoby w relacji do prawdy [Freedom of Person in Relation to Truth], „Studia Koszalińsko-Kołobrzeskie”, 8(2003), p. 136.)

${ }^{20}$ H.U. von B a $1 \mathrm{t}$ h a s a r, Theo-Logic. 1. The Truth of the World, op. cit., p. 82.

${ }^{21} \mathrm{Cf}$. the above, p. $91 \mathrm{ff}$. 
discovering and communicating the truth. But such freedom from truth leads to a loneliness of being already mentioned before.

That it why in Christianity we talk about the truth of testimony, which means that the level of openness and of intimacy have to be harmonised in all respects. Word requires image. An image provokes a certain risk: an attempt to reduce man to just one facet of his existence. It would mean that such a reductionist vision of man claims the right to determine his entire being. But such truth about man cannot be a gift to another person, as in a gift man gives all of himself, and reducing him to just one facet makes it impossible.

Ultimately it is all about in what image man expresses himself. Often the primitive theological intuition - imago Dei - is reduced to the subject as an organizer/collector of facts, opinions, interpretations that form the exterior of the person to the extent that communicating them without engaging the person does not refer to the truth about such person. And not knowing the truth about the subject, we cannot entirely trust the truth about reality communicated by him. Referring to objectivity of message is essentially referring to an undetermined model, that has no security either on the side of the subject or of the object. Therefore we need a different horizon of utterances and their understanding than objectivity of message.

\section{d) Love as a horizon of utterance and its understanding}

Getting to know the truth is possible without love, but it will always be perception in a very limited perspective. Man will learn more than enough details, but will not be able to make sense out of them. Love is therefore a wider perspective for truth. It kind of precedes truth. An example of such perception is the image of a loved one. On one hand you form an ideal notion of the person you love, while the truth of your senses shows an image apparently more real, including all imperfections. But in the name of love the imperfect (sensible) image is discarded, and the ideal one remains. It is not fictional while love lasts. Then this ideal image coming into existence between subject and object makes them both undergo a transformation. But when 
love is no more, what remains is going back to the sensible image, apparently more real, yet imperfect.

It is worthwhile to refer to a reflection suggested by Hans Urs von Balthasar. Talking about truth, he places it in the perspective of testimony, which forces one to widen the horizon of perception with love. Then learning man gives himself at the same time. Balthasar also points out that you have to discriminate between partial and absolute truth. Only partial truth can be kept by man for himself. The so a question arises about man's duty towards truth. In order to answer it, we should make it more detailed: When, to whom, to what extent and in what way truth is due? Well, it is man's duty to make truth accessible to one who has a right to it, who needs this truth and who will not abuse $\mathrm{it}^{22}$.

What is then absolute truth in man's version? It is revealing oneself partly, but with a will to fully give oneself. Whereas revealing even a greater fragment of truth about oneself without the will to give oneself is a lie. So there is no sense in saying "to miss the truth". Missing the truth means to close up, and any fragmentary showing of truth is nothing else but misleading someone into thinking he learns the whole truth. It leads to ill-conceived autonomy, that would consist in wanting to make each fragment of truth autonomous. Man's fault is not that he proposes a part of truth, but that he wants the other to be satisfied with this part, as though it were the whole truth.

Without love man is not capable of revealing the whole truth, nor can he see and evaluate it. Then man "weighs" his words. It is not about opening in love for truth, but about dosing truth, and believing each of its fragments to be absolute. Hence love of wisdom is understood as openness for the entire truth, even if it is learnt partially. However, bringing truth to the method of "weighing words" leads to a reductionist vision of truth. And this is what contemporary lie consists in.

${ }^{22}$ H.U. von B a $1 \mathrm{t}$ h a s a r, Theo-Logic. 1. The Truth of the World, op. cit., p. 114 ff. 


\section{DOES EVERYBODY HAVE A RIGHT TO THEIR PART OF THE TRUTH?}

Personal truth is more than partial truth. What binds me is not my attitude towards the unknown parts of truth, but responsibility for the learnt ones. Personal truth is so valuable that man is not responsible for the whole truth, but for the way he tries to reach it. And for what is his faithfulness to the known truth. For man it is the only truth, according to which he builds his life.

Truth is shaped and conditioned by situation, and a particular moment of revealing it is time. Time does not tear a part of truth off the whole. Quite the opposite, all the time absolute truth gets more and more concrete. Time is connected to the present, which cannot be separated from the past and the future. The present of truth comes from the past (as the forecast of the full truth) and is future-oriented (as the fulfillment of the promise to get to know the whole truth).

So the situation reveals truth in the clothing of time. In every situation of life we confront responsibility for the situation which forces us to accept the fact that we leave things unfinished. This pressure of the present encourages us to deal only with important matters, leaving aside the peripheral ones.

Seeking truth is therefore necessarily operating with only a partial point of view. It is a responsibility for decisions made in specific situations. In other words, in the temporality man is not responsible for the eternity, but he is responsible for temporality regarding eternity. The whole of all specific situations is life history. Thus man has a double view of responsibility. He is responsible for specific choices in the present. He is also responsible for the future, with a small addition: Doing everything for the future's sake would mean giving up responsibility for the present. It would be resigning from the proper seeking of truth.

Learning the truth is a bit like the allegory of Plato's cave. There are those chained to the walls, watching shadows projected on the walls of the cave. If they had the courage to turn their heads, they would see that the shadows come from the light of a fire. This light 
produces a world of shadows for the chained ones. Man will not fathom the light, if he does not turn his head. Otherwise he will only see the limits of his perception determined by his senses and un-illuminated mind. In the end the matter is not to get to know the entire truth (which is always a gift, the truth revealed). It is more about a unity in seeking the truth. A unity rooted in trust to the one who reveals and to those with whom one seeks the truth. Unity is an inspiration to take courage to turn towards light in a common quest. It is in this sense that trust is a condition of getting to know the truth.

\section{Summary}

Man is a relational being. His development, both in the personal and social aspects, assumes a relation to truth. In such communal building the classical concept of truth as the congruence of intellect and the perceived reality is not enough. It is also necessary to refer to the world of persons (subjects of perception), as a person is the place of learning and communicating the truth, and its witness, for only on personal level can truth give rise to obligation. For it to happen, however, there must be an attitude of trust created between persons.

The truth perceived by a subject is a partial one. Thus communicating it must assume its limited and incomplete nature. What is more, a subject communicates by means of words and images. And they acquire certain autonomy, eluding the subject. Therefore there is a need of trust which assumes that the subject communicates only a part of the truth, but it is accompanied by a willingness to get to know the whole truth. Truth requires a particular communicational horizon, which is love. Only by love and a willingness to be open to the full truth the learning subjects can get closer to it. The unity of seeking must be based on full trust in a person, and in such a sense trust is a condition of getting to know the Truth which is a Person.

\section{Zaufanie warunkiem poznania prawdy - perspektywa antropologiczna Streszczenie}

Człowiek jest bytem relacyjnym. Jego rozwój - zarówno w wymiarze osobistym, jak i społecznym - zakłada odniesienie do prawdy. W takim wspólnotowym budowaniu nie wystarcza jednak klasyczne rozumienie prawdy jako zgodności 
intelektu z poznawaną rzeczywistością. Chodzi również o odniesienie do świata osób (podmiotów poznania), gdyż to osoba jest miejscem poznania i komunikowania prawdy - jest świadkiem prawdy, gdyż tylko na poziomie osoby prawda może rodzić powinność. By jednak to się dokonało, pomiędzy osobami musi wytworzyć się postawa zaufania.

Poznana przez podmiot prawda jest prawdą cząstkową. Tym samym komunikowanie jej musi zakładać ograniczoność i niepełność. Co więcej, podmiot komunikuje słowem i obrazem. Te zaś zyskują swoistą autonomię, wymykając się podmiotowi. Potrzeba zatem zaufania, które zakłada, że podmiot komunikuje tylko część prawdy, ale towarzyszy mu wola poznania całej prawdy. Prawda potrzebuje więc szczególnego horyzontu komunikacyjnego jakim jest miłość. Tylko w miłości i woli otwarcia na pełnię prawdy poznające podmioty mogą się do niej zbliżać. Jedność poszukiwania musi opierać się na pełnym zaufaniu osobie i w tym sensie zaufanie jest warunkiem poznania Prawdy, która jest Osobą.

Słowa klucze: prawda, poznanie, komunikowanie prawdy, jedność, zaufanie.

Key words: truth, perception/learning, communicating the truth, unity, trust

Nota o autorze: Ks. dr Jarosław A. Sobkowiak - zainteresowania badawcze: etyka, aksjologia, antropologia, teologia moralna, komunikacja norm moralnych w kontekście „nowego porządku moralnego”. Magisterium z teologii w Katolickim Uniwersytecie Lubelskim, studia specjalistyczne w Instytucie „Centre Sèvres” w Paryżu. Od 2006 roku członek zarządu Stowarzyszenia Teologów Moralistów. Od 2012 roku prodziekan Wydziału Teologicznego UKSW.

\section{Bibliografia:}

Arystoteles, Metafizyka, (tłum.) K. Leśniak, PWN, Warszawa 2009.

Arystoteles, Etyka nikomachejska, (tłum.) D. Gromska, PWN, Warszawa 2003.

Balthasar H.U. von, Teologika. 1. Prawda świata, (tłum.) J. Zychowicz, Kraków 2003.

Dębowski J., Prawda i warunki jej możliwości, Olsztyn 2010.

Głowala M., Łatwość i trudność poznania prawdy, w: J. Jaskóła, A. Olejarczyk

(red.), Prawda a metoda. O prawdzie, cz.2 Wrocław 2006, s. 49-56.

Kaeppelin Ph., Dire la vérité. Dramatique du désir, in: Philosophie, 8, La vérité,

Institut Catholique de Paris, ed. J. Greisch, Paris 1983

Katechizm Kościoła Katolickiego, Poznań 2012. 
Misiek J., O filozoficznych definicjach pojęcia prawdy, „Kwartalnik filozoficzny”, 32(2004), b. 2, s. 24-25.

Ostasz L., Czym jest prawda w szerokim tego stowa znaczeniu?, Warszawa 2010.

Platon, Sofista, Polityk, (tłum.) W. Witwicki, Kęty 2002.

Putnam H., Wiele twarzy realizmu i inne eseje, (tłum.) A. Grobel, PWN, Warszawa 1998.

Sienkiewicz E., Wolność osoby w relacji do prawdy, „Studia Koszalińsko-Kołobrzeskie" 8(2003), s. 136.

Sobkowiak J.A., Prawda w społeczeństwie pluralistycznym i tolerancyjnym, „Teologia i Moralność", 2(2007), s.

Woleński J., Epistemologia, t. 1. Zarys historyczny i problemy metateoretyczne, Ureus, Kraków, 2000.

Ziemińska R., Czy można dziś obronić absolutyzm w teorii prawdy?, „Acta Universitatis Wratislaviensis" 2006 n 2856, v. XLIV: Prawda a metoda [Truth and Method], part II O prawdzie [On Truth], ed. J. Jaskóła, A. Olejarczyk, Wrocław 2006. 